\title{
Magnesium Absorption by Lactating Dairy Cows on a Grass Silage- Based Diet Supplied with Different Potassium and Magnesium Levels
}

\author{
K. Holtenius, ${ }^{1}$ C. Kronqvist, E. Briland, and R. Spörndly \\ Department of Animal Nutrition and Management, Swedish University of Agricultural Sciences (SLU), SE-753 23 Uppsala, Sweden
}

\begin{abstract}
The objective of the present study was to investigate the interactions of dietary $\mathrm{K}$ intake typical for foragebased diets on $\mathrm{Mg}$ balance in lactating dairy cows. Six lactating multiparous cows of the Swedish Red and White breed in midlactation were used. Two concentrations of $\mathrm{Mg}$ ( 1.9 and $4.3 \mathrm{~g} / \mathrm{kg}$ of dry matter) and 3 concentrations of $\mathrm{K}(19,28$, and $37 \mathrm{~g}$ of $\mathrm{K} / \mathrm{kg}$ of dry matter) were obtained by adding appropriate amounts of $\mathrm{MgO}$ and $\mathrm{KHCO}_{3}$ to the diet. The experimental setup was a $6 \times 6$ Latin square design with a $2 \times 3$ factorial arrangement of treatments. Each experimental period lasted $14 \mathrm{~d}$ (9-d treatment adaptation period and 5-d data collection). There was no effect of $\mathrm{Mg}$ or K dietary supplementation on milk yield. Supplementing the ration with $\mathrm{K}$ did not significantly affect the $\mathrm{Mg}$ apparent absorption, urinary Mg excretion, or plasma Mg concentration. The $\mathrm{Mg}$ balance, estimated as the $\mathrm{Mg}$ losses in milk and urine, was positively related to $\mathrm{Mg}$ intake but not affected by $\mathrm{K}$ intake. The amount of apparently digested $\mathrm{Mg}$ was related to the $\mathrm{Mg}$ balance. The apparent digestibility ranged from 0.12 to 0.24 with no effect of mineral supplementation. There was a significant curvilinear relationship between plasma $\mathrm{Mg}$ and urinary $\mathrm{Mg}$ excretion, with a more marked increase in urinary $\mathrm{Mg}$ excretion at higher plasma levels of $\mathrm{Mg}$.
\end{abstract}

Key words: magnesium, potassium, absorption, dairy cow

\section{INTRODUCTION}

Magnesium is a mineral essential for various functions in the mammalian cells. If the outflow of $\mathrm{Mg}$ with milk, urine, and feces exceed inflow, hypomagnesemia occurs because of the lack of hormonal mechanisms of homeostasis (Martens and Schweigel, 2000). The K content of the ration is considered an important risk factor in the development of hypomagnesemia in rumi-

Received April 24, 2007.

Accepted October 25, 2007.

${ }^{1}$ Corresponding author: kjell.holtenius@huv.slu.se nants because it reduces the digestibility of $\mathrm{Mg}$ (Greene et al., 1983; Martens and Schweigel, 2000). In practice, the $\mathrm{K}$-induced reduction in $\mathrm{Mg}$ digestibility is often overcome by adding different $\mathrm{Mg}$ sources to the diet. Weiss (2004) compiled data from 8 experiments with lactating dairy cows in which apparent digestibility of $\mathrm{Mg}$ was measured by using total collection of feces and urine. The apparent Mg digestibility linearly decreased by 0.075 per percentage unit of $\mathrm{K}$ in the diet. The average $\mathrm{K}$ level in the diets was $16 \mathrm{~g} / \mathrm{kg}$ of DM. However, in many areas with intensive dairy production, $\mathrm{K}$ content in forage is often $>30 \mathrm{~g} / \mathrm{kg}$ of DM (Fisher et al., 1994; Schonewille et al., 2000). The forestomachs are the main site of $\mathrm{Mg}$ absorption in adult ruminants (Tomas and Potter, 1976; Greene et al., 1983). Most of the $\mathrm{Mg}$ is absorbed through the rumen epithelium by transcellular systems. One system is sensitive to $\mathrm{K}$ and uses the potential difference of the apical membrane as the major driving force. This system works primarily at low ruminal $\mathrm{Mg}$ concentrations. The second system is $\mathrm{K}$-insensitive and the absorbed $\mathrm{Mg}$ ion is exchanged with hydrogen ions or $\mathrm{Mg}$ is cotransported with anions. The K-insensitive system is assumed to work at higher ruminal $\mathrm{Mg}$ concentrations (Martens and Schweigel, 2000). In vitro studies indicate that $\mathrm{Mg}$ solubility declines sharply as ruminal $\mathrm{pH}$ rises above 6.5 (Dalley et al., 1997). However, in in vivo studies in sheep, ruminal $\mathrm{pH}$ did not significantly affect $\mathrm{Mg}$ absorption (Giduck et al., 1988). Malabsorption of $\mathrm{Mg}$ from the forestomachs is not compensated for in the intestines (Tomas and Potter, 1976). Excess Mg absorbed from the diet is excreted in the urine. Any change in $\mathrm{Mg}$ balance is counterbalanced by corresponding changes in urinary excretion (Ram et al., 1998). Thus, urinary $\mathrm{Mg}$ is a good indicator of whether a sufficient amount of available $\mathrm{Mg}$ is ingested (Martens and Schweigel, 2000). Magnesium toxicosis is not evident as a clinical problem. However, an excessive addition of $\mathrm{Mg}$ may decrease palatability and cause diarrhea because of osmotic effects (NRC, 2001). Information about the effects of high levels of K on $\mathrm{Mg}$ absorption in lactating cows is limited. The aim of the present study was to investigate the interactions of dietary $\mathrm{K}$ intake typical of forage-based diets on $\mathrm{Mg}$ balance in lactating dairy cows. 
Table 1. Dry matter content, chemical composition, and calculated values for ME of feeds

\begin{tabular}{lcc}
\hline Item & Silage & Concentrate \\
\hline $\mathrm{DM}, \%$ & 38 & 89 \\
$\mathrm{ME}, \mathrm{MJ} / \mathrm{kg}$ of DM & 11.1 & 13.6 \\
$\mathrm{CP}, \mathrm{g} / \mathrm{kg}$ of DM & 72 & 201 \\
$\mathrm{AAT},{ }^{2}$ g/kg of DM & 158 & 122 \\
$\mathrm{PBV}$, g/kg of DM & 41 & 10 \\
$\mathrm{Ash}, \mathrm{g} / \mathrm{kg}$ of DM & 87.6 & \\
$\mathrm{NH}_{3}-\mathrm{N}, \%$ of N & 5.2 & \\
pH & 4.0 & \\
\hline
\end{tabular}

${ }^{1} \mathrm{AAT}=\mathrm{AA}$ absorbed in the small intestine.

${ }^{2} \mathrm{PBV}=$ protein balance in the rumen .

\section{MATERIALS AND METHODS}

\section{Cows and Experimental Design}

The animal procedures were approved by the Uppsala Local Ethics Committee. Six lactating multiparous cows (parities 2 to 4) of the Swedish Red and White Breed with mean BW of $606 \mathrm{~kg}$ (range 570 to $685 \mathrm{~kg}$ ) were used. The cows were not pregnant and they were milked twice daily. The average DIM at the start of the experiment were 180 (150 to 209). The cows were held indoors in individual stalls with straw and sawdust as bedding. They had free access to water. The experimental setup was a $6 \times 6$ Latin square design with a $2 \times 3$ factorial arrangement of treatments aiming at 2.0 and $4.5 \mathrm{~g}$ of $\mathrm{Mg} / \mathrm{kg}$ of DM and 18,28 , and $38 \mathrm{~g}$ of $\mathrm{K} / \mathrm{kg}$ of DM. The design was balanced for carryover effects. Each experimental period lasted $14 \mathrm{~d}$, and the first $9 \mathrm{~d}$ was the pretreatment adaptation period. The cows were randomly assigned to each sequence of feeding.

\section{Diets}

The cows were individually fed restricted amounts covering the requirements based on the average milk yield during the first $4 \mathrm{~d}$ of each experimental period according to the Swedish feeding recommendations (Spörndly, 2003). The diet consisted of grass silage and concentrate fed separately, with a constant ratio of $60 \%$ silage and $40 \%$ concentrate on a DM basis. Both silage and concentrate were fed 4 times daily, at 0600, 0900, 1200 , and $1700 \mathrm{~h}$, in separate buckets by automatic feeding wagons. The composition of the feeds is shown in Table 1. Appropriate amounts of $\mathrm{MgO}$ and $\mathrm{KHCO}_{3}$ were fed on top of each ration and were manually mixed into the silage. The particle size of $\mathrm{MgO}$ was less than $250 \mu \mathrm{m}$ in diameter.

\section{Collection of Samples}

Samples from silage were collected every day during each experimental period. The samples were dried at $60^{\circ} \mathrm{C}$ in a forced-air oven for $24 \mathrm{~h}$ and ground in a hammer mill (1-mm screen). Samples from 1 period were pooled to obtain 1 sample from each of the 6 periods. Orts from silage and concentrates were collected daily and pooled. Orts were treated according to the same routines as the silage. Spot samples of urine were collected once daily during the last $5 \mathrm{~d}$ of each period between 0800 and $1000 \mathrm{~h}$. Twenty milliliters of urine was then pooled and stored at $-20^{\circ} \mathrm{C}$. Rumen fluid was collected by using an esophageal tube at $1200 \mathrm{~h}$ on $\mathrm{d}$ 12. Blood samples were taken on $d 11$ and 13 between 0800 and $1000 \mathrm{~h}$ from the coccygeal artery or vein into evacuated Vacutainer tubes containing sodium heparin as anticoagulant (Venoject, Terumo Europe N.V., Leuven, Belgium). The samples were centrifuged for $15 \mathrm{~min}$ at $1,800 \times g$ within $1 \mathrm{~h}$ after sampling, and the plasma was harvested and stored at $-20^{\circ} \mathrm{C}$ until analyzed. Morning and afternoon grab samples of feces were collected twice daily during the last $5 \mathrm{~d}$ of each period. Individual cow fecal samples were composited on an equal weight basis and frozen at $-20^{\circ} \mathrm{C}$. After each period, the samples were thawed and individual samples from each cow and collection period were merged and thoroughly mixed. A representative sample was then freeze-dried and stored until analysis. Milk production was registered daily, morning and evening, during the 5 last days, and a sample of milk was taken at each milking and preserved with bronopol and stored in a refrigerator up to $7 \mathrm{~d}$ until analysis for protein, fat, and lactose. An additional $10 \mathrm{~mL}$ of milk from each sampling was pooled and frozen $-20^{\circ} \mathrm{C}$ until analyzed.

\section{Analyses}

Ground material of feed and feces was dried at $105^{\circ} \mathrm{C}$ overnight before analysis. Feeds were analyzed for CP by a fully automated Kjeldahl procedure (Technicon, Solna, Sweden). Metabolizable energy in the feeds was calculated from in vitro digestibility (Lindgren, 1979). Amino acids absorbed in the small intestine and protein balance in the rumen were calculated according to the Nordic Protein Evaluation System as described in the Swedish Feed Tables for Ruminants (Spörndly, 2003). The $\mathrm{Mg}$ and $\mathrm{K}$ concentrations in feeds and feces were determined by optical emission spectral analysis with inductively coupled plasma (Spectro Analytical Instruments GmbH \& Co. KG, Kleve, Germany). Samples were analyzed for acid insoluble ash, which was used as an internal marker to determine apparent total-tract Mg digestibility (van Keulen and Young, 1977). The rumen fluid $\mathrm{pH}$ was determined with a $\mathrm{pH}$ meter (MP125, Mettler-Toledo, Schwerzenbach, Switzerland) immediately following collection. Before analysis, the rumen fluid was filtered through a filter paper and 
Table 2. Intake of the experimental diets

\begin{tabular}{|c|c|c|c|c|c|c|}
\hline \multirow[b]{2}{*}{ Item } & \multicolumn{3}{|c|}{ Low Mg } & \multicolumn{3}{|c|}{ High Mg } \\
\hline & Low $\mathrm{K}$ & Medium K & High $\mathrm{K}$ & Low $\mathrm{K}$ & Medium K & High $\mathrm{K}$ \\
\hline Silage, $\mathrm{kg}$ of $\mathrm{DM} / \mathrm{d}$ & 9.3 & 9.4 & 9.7 & 9.7 & 9.6 & 9.2 \\
\hline Concentrate, $\mathrm{kg}$ of $\mathrm{DM} / \mathrm{d}$ & 5.9 & 6.1 & 6.3 & 6.3 & 6.3 & 6.1 \\
\hline $\mathrm{MgO}, \mathrm{g}$ of $\mathrm{DM} / \mathrm{d}$ & 0 & 0 & 0 & 0.065 & 0.064 & 0.060 \\
\hline $\mathrm{KHCO}_{3}, \mathrm{~g}$ of $\mathrm{DM} / \mathrm{d}$ & 0 & 0.377 & 0.788 & 0 & 0.384 & 0.716 \\
\hline Total DM, kg of DM/d & 15.3 & 15.9 & 16.9 & 16.2 & 16.4 & 16.1 \\
\hline
\end{tabular}

centrifuged for $5 \mathrm{~min}$ at $16,000 \times \mathrm{g}$. Proteins in the pooled milk samples were precipitated by addition of 10\% TCA 1:1 by volume, centrifuged for $15 \mathrm{~min}$ at $16,000 \times g$, and the supernatant harvested. The plasma, rumen fluid, milk, and urine concentrations of $\mathrm{Mg}$ were analyzed by using a quantitative colorimetric method (Magnesium LiquiColor, Stanbio Laboratory, Boerne, TX). Milk composition was determined by Fouriertransform infrared spectroscopy (Fossomatic 5000, N Foss Electric, Hillerød, Denmark). Creatinine in urine was analyzed on a Technicon Auto Analyzer II [Technicon, Solna, Sweden (Technicon method no. SE40011FH4)].

\section{Statistical Analysis and Calculations}

Analysis of variance was performed by using PROC MIXED (SAS Institute, 2001). Period and treatment were fixed factors and cow was a random effect. Before statistical analysis, means of the 2 plasma $\mathrm{Mg}$ values taken on $\mathrm{d} 11$ and 13 were calculated. The Mg losses in urine were calculated, assuming a daily urinary excretion of $29 \mathrm{mg}$ of creatinine/ $\mathrm{kg}$ of BW (Valadares et al., 1999).

\section{RESULTS}

The DMI did not vary much between treatments (Table 2). There was no effect of Mg or K dietary supplementation on milk yield (Table 3). However, the milk production decreased by almost $6 \mathrm{~kg}$ from period 1 to 6 (data not shown). The $\mathrm{Mg}$ contents in the consumed diets were 1.9 and $4.3 \mathrm{~g}$ of $\mathrm{Mg} / \mathrm{kg}$ of DM, respectively, slightly lower than expected. The $\mathrm{K}$ contents were 19 , 28 , and $37 \mathrm{~g}$ of $\mathrm{K} / \mathrm{kg}$ of $\mathrm{DM}$, which was close to the expected content.

Plasma $\mathrm{Mg}$ concentrations were significantly influenced by dietary $\mathrm{Mg}$ intake, but not by $\mathrm{K}$ intake (Table 3 ). The $\mathrm{Mg}$ level in rumen fluid was higher when the cows were fed the diets with a high $\mathrm{Mg}$ concentration but was not affected by dietary differences in $\mathrm{K}$ intake. The rumen fluid $\mathrm{pH}$ increased when the diet was supplemented with $\mathrm{K}$, whereas $\mathrm{Mg}$ supplementation did not affect the $\mathrm{pH}$.

The Mg balance, estimated as the Mg losses in milk and urine, was positively related to $\mathrm{Mg}$ intake but not to $\mathrm{K}$ intake. The amount apparently digested $\mathrm{Mg}$ was linearly related to the $\mathrm{Mg}$ balance (Figure 1). There was a significant $(P<0.001)$ curvilinear relationship between plasma $\mathrm{Mg}$ and urinary $\mathrm{Mg}$ excretion (Figure 2 ). The milk concentration was affected neither by the dietary $\mathrm{Mg}$ level nor by the $\mathrm{K}$ level, but there was an interaction between the dietary $\mathrm{Mg}$ and $\mathrm{K}$ levels. In cows not supplemented with extra $\mathrm{Mg}$, the highest milk $\mathrm{Mg}$ concentration was observed when the dietary $\mathrm{K}$ level was highest (Table 3). On the other hand, in cows supplemented with $\mathrm{Mg}$, the lowest milk Mg concentration was seen at the highest $\mathrm{K}$ supplementation level. The $\mathrm{K}$ level in the consumed diet did not affect the calculated absorption of $\mathrm{Mg}$. The amount of apparently absorbed $\mathrm{Mg}$ was significantly influenced by dietary $\mathrm{Mg}$ intake, but not by $\mathrm{K}$ intake (Table 4). The urinary excretion of $\mathrm{Mg}$ was higher when the cows received the high-Mg diets but was not affected by the $\mathrm{K}$ concentration in the diet. The $\mathrm{Mg}$ digestibility ranged from 12.5

Table 3. Magnesium concentrations in ruminal fluid, plasma, and milk and ruminal $\mathrm{pH}$, and daily milk yield in cows ( $\mathrm{n}=6$ ) fed different $\mathrm{Mg}$ and $\mathrm{K}$ supplements

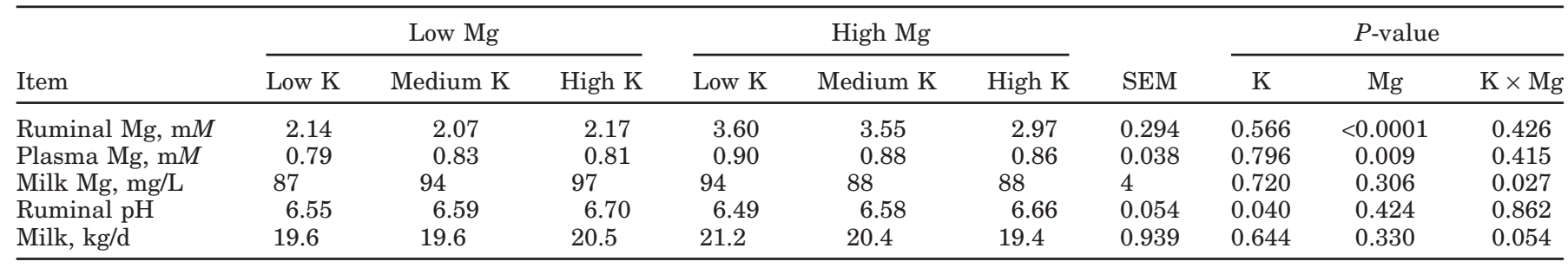




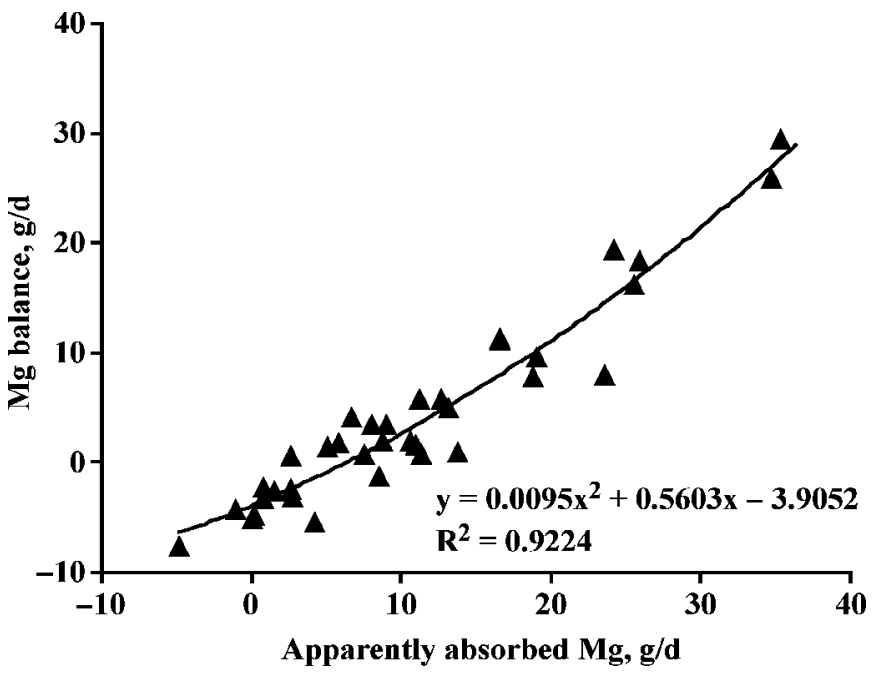

Figure 1. Relationship between daily apparently absorbed $\mathrm{Mg}$ and the $\mathrm{Mg}$ balance expressed as $\mathrm{Mg}$ intake minus $\mathrm{Mg}$ excreted in urine and milk $(\mathrm{n}=36)$.

to $24.5 \%$ (Table 4). The different mineral supplements did not affect the $\mathrm{Mg}$ digestibility.

\section{DISCUSSION}

In this study, addition of $\mathrm{K}$ to the ration of lactating dairy cows did not affect the Mg balance because apparent $\mathrm{Mg}$ absorption, urinary $\mathrm{Mg}$ excretion, and plasma $\mathrm{Mg}$ concentration were not affected. The results are in conflict with results from previous studies (Fisher et al., 1994; Jittakhot et al., 2004). Fisher et al. (1994) supplemented lactating cows with $\mathrm{K}$, which reduced urinary $\mathrm{Mg}$ excretion, indicating a reduced $\mathrm{Mg}$ uptake in lactating cows, but there was no significant effect of $\mathrm{K}$ on apparent $\mathrm{Mg}$ digestibility. In the study of dry cows by Jittakhot et al. (2004), the Mg content of the diets was far above the requirements (NRC, 2001), which might have affected the results.

In sheep, the depressive effects of high ruminal $\mathrm{K}$ concentrations were much more pronounced at ruminal $\mathrm{Mg}$ concentrations below $2 \mathrm{~m} M$ (Care et al., 1984; Ram et al., 1998). In the present study, the rumen fluid concentration of $\mathrm{Mg}$ was above $2 \mathrm{mM}$ even when the cows were subjected to treatments with no $\mathrm{Mg}$ supplementation. The relatively high level of $\mathrm{Mg}$ in rumen fluid may have inhibited the negative effects of $\mathrm{K}$. However, it must be emphasized that the rumen concentration of $\mathrm{Mg}$ was determined on only one occasion, approximately $3 \mathrm{~h}$ after feeding. It could not be excluded that the $\mathrm{Mg}$ content was occasionally below $2 \mathrm{~m} M$ during the study. Furthermore, $\mathrm{Mg}$ metabolism differs between sheep and cattle, and the validity of sheep as a model for $\mathrm{Mg}$ metabolism in cattle has been questioned (Un-

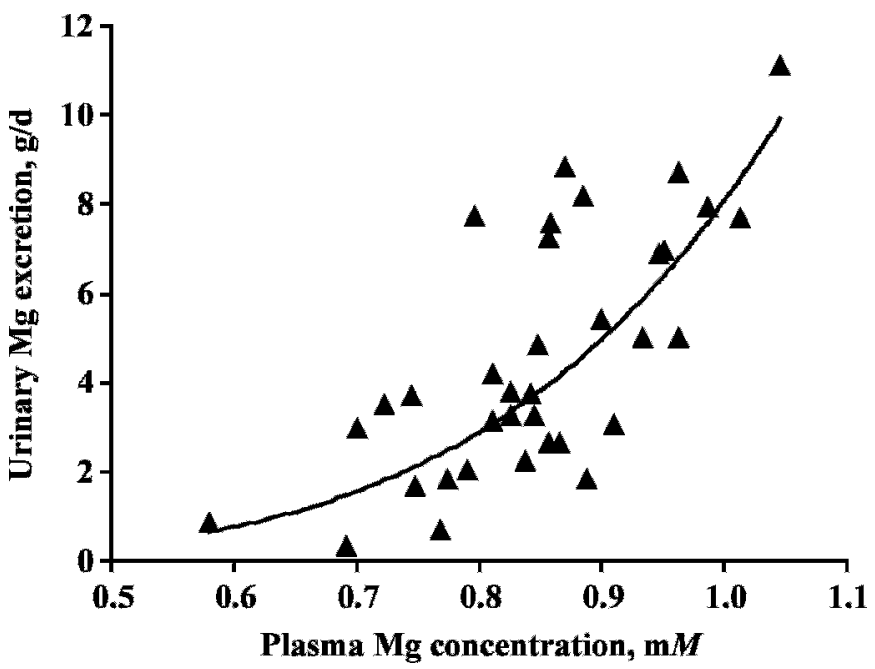

Figure 2. Relationship between plasma $\mathrm{Mg}$ concentration and urinary $\mathrm{Mg}$ excretion $(\mathrm{n}=36)$.

derwood and Suttle, 1999). The Mg apparent digestibility ranging from approximately 0.12 to 0.24 is in line with data reported by Weiss (2004) for lactating dairy cows. The coefficient of absorption for $\mathrm{Mg}$ from $\mathrm{MgO}$ has been set at $50 \%$ (NRC, 2001). A slightly higher digestibility in Mg-supplemented cows would thus have been expected. In this study, however, the apparent digestibility did not differ significantly between $\mathrm{Mg}$ supplemented and nonsupplemented cows $(P=0.16)$, although the digestibility was numerically higher in the treatment groups supplemented with $\mathrm{Mg}$.

The Mg concentration in milk was slightly lower than published values related to dairy cows of the Holstein and Ayrshire breeds and the Jersey-Friesian crossbreed (Fisher et al., 1994; Thielen et al., 2001; Gaucheron, 2005). It cannot be excluded that cows of the Swedish Red and White breed have a lower milk concentration of $\mathrm{Mg}$. There was no effect of $\mathrm{Mg}$ or $\mathrm{K}$ supplementation on the $\mathrm{Mg}$ concentration in milk, but there was an interaction between $\mathrm{Mg}$ and Kintake. Thus, on low-Mg diets, the highest $\mathrm{Mg}$ levels in milk were observed when the cows were given the high $\mathrm{K}$ level. On the other hand, in cows receiving the high $\mathrm{Mg}$ level, the highest $\mathrm{Mg}$ concentration in milk occurred when no extra $\mathrm{K}$ was given. We have no explanation for this observation.

The urine excretion of $\mathrm{Mg}$ and plasma $\mathrm{Mg}$ were positively associated in a curvilinear action. Schonewille et al. (2000) have also shown such an association in dry cows. However, in the present study with lactating cows, the urine excretion was markedly higher. It is possible that there is a productivity-related increment of inescapable urinary $\mathrm{Mg}$ losses in lactating cows.

The amount of $\mathrm{Mg}$ apparently absorbed increased when the cows were fed the high-Mg diets. This was 
Table 4. Balance of $\mathrm{Mg}$ in lactating cows fed diets with different $\mathrm{Mg}$ and $\mathrm{K}$ contents

\begin{tabular}{|c|c|c|c|c|c|c|c|c|c|c|}
\hline \multirow[b]{2}{*}{ Item } & \multicolumn{3}{|c|}{ Low Mg } & \multicolumn{3}{|c|}{ High Mg } & \multirow[b]{2}{*}{ SEM } & \multicolumn{3}{|c|}{$P$-value } \\
\hline & Low $\mathrm{K}$ & Medium K & High $\mathrm{K}$ & Low $\mathrm{K}$ & Medium K & High K & & K & $\mathrm{Mg}$ & $\mathrm{K} \times \mathrm{Mg}$ \\
\hline Intake, g/d & 29.6 & 30.0 & 31.1 & 71.1 & 70.7 & 67.0 & $\mathrm{ND}^{1}$ & ND & ND & ND \\
\hline Feces, g/d & 22.5 & 26.3 & 25.5 & 54.4 & 53.9 & 52.0 & 3.08 & 0.842 & $<0.0001$ & 0.625 \\
\hline Absorption, g/d & 7.1 & 3.8 & 5.6 & 17.2 & 16.8 & 15.1 & 2.64 & 0.676 & $<0.0001$ & 0.725 \\
\hline Digestibility, \% & 22.5 & 12.5 & 18.0 & 23.8 & 24.5 & 23.7 & 5.80 & 0.224 & 0.160 & 0.608 \\
\hline Urine, $g / d$ & 3.5 & 2.9 & 3.0 & 7.2 & 5.3 & 7.1 & 1.12 & 0.891 & $<0.0001$ & 0.563 \\
\hline Milk, g/d & 1.7 & 1.8 & 2.0 & 2.0 & 1.8 & 1.7 & 0.09 & 0.830 & 0.858 & 0.003 \\
\hline Balance, g/d & 1.8 & -0.9 & 0.6 & 7.9 & 9.6 & 6.3 & 2.46 & 0.39 & $<0.001$ & 0.537 \\
\hline
\end{tabular}

${ }^{1}$ Not determined.

reflected by an increased daily excretion of $\mathrm{Mg}$. As expected, there was a significant relationship between the amount $\mathrm{Mg}$ apparently absorbed and the calculated balance between intake and excretion (Figure 1). It is interesting that the lactating cows in the present study excreted nearly $5 \mathrm{~g}$ of $\mathrm{Mg} / \mathrm{d}$ even without apparent absorption of dietary $\mathrm{Mg}$. Approximately $2 \mathrm{~g}$, on average, was excreted with the milk and the remaining amount was excreted in the urine. It has been established in cattle that $\mathrm{Mg}$ homeostasis is in equilibrium when the daily $\mathrm{Mg}$ excretion is approximately $2.5 \mathrm{~g}$ (Kemp and Geurink, 1978; Mayland, 1988). In the present study, more than $44 \%$ of the cows that were not supplemented with $\mathrm{Mg}$ excreted less than $2.5 \mathrm{~g}$ of $\mathrm{Mg} / \mathrm{d}$ in the urine, indicating a marginal $\mathrm{Mg}$ supply. Thus, a dietary supply of $1.9 \mathrm{~g}$ of $\mathrm{Mg} / \mathrm{kg}$ of DM was too low for these lactating cows. According to the NRC (2001), $1.8 \mathrm{~g}$ of $\mathrm{Mg} / \mathrm{d}$ would be accurate for the cows in the present study, assuming that $\mathrm{K}$ does not interfere with the $\mathrm{Mg}$ absorption. However, Weiss (2004) has shown that lactating cows had to consume an additional $18 \mathrm{Mg} / \mathrm{d}$ for every 1 percentage unit increase in dietary $\mathrm{K}$ above $1 \%$ to maintain the same intake of digestible $\mathrm{Mg}$ as that consumed when fed a diet with $1 \% \mathrm{~K}$. In the present study, the $\mathrm{K}$ intake of cows receiving no extra $\mathrm{K}$ supplementation was $19 \mathrm{~g}$ of $\mathrm{K} / \mathrm{kg}$ of DM. It is possible that this $\mathrm{K}$ level caused a reduction in $\mathrm{Mg}$ absorption.

Any surplus of absorbed $\mathrm{Mg}$ is quantitatively excreted in urine (Martens and Schweigel, 2000). It is therefore intriguing that the amount of $\mathrm{Mg}$ apparently absorbed was higher than that excreted. The cows were not pregnant and were virtually not growing. Thus, if the apparently absorbed $\mathrm{Mg}$ at least meets the outflow in milk, the surplus will be excreted in urine. It cannot be excluded that the techniques used, with indirect measurements of $\mathrm{Mg}$ apparent absorption and urinary excretion, may have caused systematic errors.

The solubility of $\mathrm{Mg}$ is negatively related to rumen fluid $\mathrm{pH}$ (Dalley et al., 1997). In the present study, the rumen fluid $\mathrm{pH}$ was elevated less than $0.2 \mathrm{pH}$ units in cows supplemented with $\mathrm{KHCO}_{3}$, but $\mathrm{K}$ intake did not affect the concentration of rumen-soluble $\mathrm{Mg}$. It is possible that the change in $\mathrm{pH}$ was too small to induce significant effects on $\mathrm{Mg}$ solubility. The results of Erdman et al. (1980) corroborate the observation that $\mathrm{MgO}$ supplementation did not affect rumen fluid $\mathrm{pH}$ in lactating cows.

In the present study with cows consuming $4.3 \mathrm{~g}$ of $\mathrm{Mg} / \mathrm{kg}$ of DM, the consistency of the feces was judged as much wetter (data not shown). This is in line with observations that excess dietary Mg intake causes diarrhea in ruminants as well as in humans (Chester-Jones et al., 1990; Fine et al., 1991).

\section{CONCLUSIONS}

In this trial with lactating dairy cows, an increased $\mathrm{K}$ intake did not negatively affect apparent $\mathrm{Mg}$ absorption. It is possible that the requirement of $\mathrm{Mg}$ supplementation to lactating dairy cows fed K-rich diets has been overstated. However, it must be emphasized that the present study covered only diets with $\mathrm{K}$ levels from 19 to $37 \mathrm{~g} / \mathrm{kg}$ of DM. The results further suggest that the inevitable losses of $\mathrm{Mg}$ in urine are higher in lactating cows than in dry cows.

\section{ACKNOWLEDGMENTS}

Financial support from the Swedish Farmers Foundation for Agricultural Research (No. 0430045; Stockholm, Sweden) is gratefully acknowledged. The authors thank Gunilla Helmersson, Håkan Wallin, and Camilla Andersson for technical assistance and for performing the analyses.

\section{REFERENCES}

Care, A. D., R. C. Brown, A. R. Farrar, and D. W. Pickard. 1984. Magnesium absorption from the digestive tract of sheep. Q. J. Exp. Physiol. 69:577-587.

Chester-Jones, H., J. P. Fontenot, and H. P. Veit. 1990. Physiological and pathological effects of feeding high levels of magnesium to steers. J. Anim. Sci. 68:4400-4413. 
Dalley, D. E., P. I. Isherwood, A. R. Sykes, and A. B. Robson. 1997. Effect of in vitro manipulation of $\mathrm{pH}$ on magnesium solubility in ruminal and caecal digesta in sheep. J. Agric. Sci. 129:107-111.

Erdman, R. A., R. L. Botts, R. W. Hemken, and L. S. Bull. 1980. Effect of dietary sodium bicarbonate and magnesium oxide on production and physiology in early lactation. J. Dairy Sci. 63:923-930.

Fine, C., A. Santa Ana, and J. S. Fordtran. 1991. Diagnosis of magnesium-induced diarrhea. N. Engl. J. Med. 324:1012-1017.

Fisher, L. J., N. Dinn, R. M. Tait, and J. A. Shelford. 1994. Effect of level of dietary potassium on the absorption and excretion of calcium and magnesium by lactating cows. Can. J Anim. Sci. 74:503-509.

Gaucheron, F. 2005. The minerals of milk. Repr. Nutr. Dev. 45:473-483.

Giduck, S. A., J. P. Fontenot, and S. Rahnema. 1988. Effect of ruminal infusion of glucose, volatile fatty acids and hydrochloric acid on mineral metabolism in sheep. J. Anim. Sci. 66:532-542.

Greene, L. W., J. P. Fontenot, and K. E. Webb. 1983. Site of magnesium and other macromineral absorption in steers fed high levels of potassium. J. Anim. Sci. 57:503-510.

Jittakhot, S., J. T. Schonewille, H. Wouterse, A. W. Uijttewaal, C. Yuangklang, and A. C. Beynen. 2004. Increasing magnesium intakes in relation to magnesium absorption in dry cows. J. Dairy Res. 71:297-303.

Kemp, A. and, J. H. Geurink. 1978. Grassland farming and minerals in cattle. Neth. J. Agric. Sci. 26:161-169.

Lindgren, E. 1979. Vallfodrets näringsvärde bestämt in vitro och med olika laboratoriemetoder (in Swedish with English summary). Rapport 45. Dept. Anim. Nutr. Mgmt., Swedish Univ. Agric. Sci. (SLU), Uppsala, Sweden.

Martens, H., and M. Schweigel. 2000. Pathophysiology of grass tetany and other hypomagnesemias: Implication for clinical management. Vet. Clin. North Am. Food Anim. Pract. 16:339-368.
Mayland, H. 1988. Grass tetany. Pages 511-523 in The Ruminant Animal: Digestive Physiology and Nutrition. D. C. Church, ed. Prentice Hall, Upper Saddle River, NJ.

NRC. 2001. Nutrient Requirements for Dairy Cattle 7th rev. ed. Natl. Acad. Press, Washington, DC.

Ram, L., J. T., Schonewille, H. Martens, A. T. van't Klooster, and A. C. Beynen. 1998. Magnesium absorption by wethers fed potassium bicarbonate in combination with different dietary magnesium concentrations. J. Dairy Sci. 81:2485-2492.

SAS Institute. 2001. SAS/Stat Software. Release 8.2. SAS Inst. Inc., Cary, NC

Schonewille, J. T., A. T. van't Klooster, H. Wouterse, and A. C. Beynen. 2000. Time courses of plasma magnesium concentrations and urinary magnesium excretion in cows subjected to acute changes in potassium intake. Vet. Quart. 22: 136-140.

Spörndly, R. 2003. Fodertabeller för idisslare. Rapport 257. Institutionen för husdjurens utfodring och vård, Dept. Anim. Nutr. Mgmt., Swedish Univ. Agric. Sci. (SLU), Uppsala, Sweden. (In Swedish)

Thielen, M., J. R. Sedcole and, A. R. Sykes. 2001. Changes in plasma, milk and urinary concentrations in pasture-fed dairy cows in early lactation. Proc. N. Z. Soc. Anim. Prod. 61:152-155.

Tomas, F. M., and B. J. Potter. 1976. The effect and site of action of potassium upon magnesium absorption in sheep. Austr. J. Agric. Res. 27:873-880.

Underwood, E. J., and N. F. Suttle. 1999. Magnesium. Pages 149184 in The Mineral Nutrition of Livestock. CABI Publishing, Wallington, UK.

Valadares, R. F., G. A. Broderick, S. C. Valadares Filho, and M. K. Clayton. 1999. Effect of replacing alfalfa silage with high moisture corn on ruminal protein synthesis estimated from excretion of total purine derivatives. J. Dairy Sci. 82:2686-2696.

van Keulen, J., and B. Young. 1977. Evaluation of acid insoluble ash as a natural marker in mineral digestibility studies. J. Anim. Sci. 4:282-287.

Weiss, W. P. 2004. Macromineral digestion by lactating dairy cows: Factors affecting digestibility of magnesium. J. Dairy Sci. 87:2167-2171. 